\title{
Pengaruh Pengenceran Lindi Dan Penambahan Bakteri Starter Terhadap Pertumbuhan Tanaman Pangan
}

\author{
Nur Diana Safitri dan Wahyono Hadi \\ Departemen Teknik Lingkungan, Fakultas Teknik Sipil dan Perencanaan, \\ Institut Teknologi Sepuluh Nopember (ITS) \\ Jl. Arief Rahman Hakim, Surabaya 60111 Indonesia \\ e-mail:wahyonohadi@yahoo.com
}

\begin{abstract}
Abstrak-Permasalahan mengenai lindi sampah merupakan salah satu dampak dari timbulan sampah. Timbulan sampah menghasilkan lindi yang dapat mencemari lingkungan. Salah satu cara untuk mengurangi dampak adanya lindi adalah dengan memanfaatkannya menjadi pupuk. Dalam pemanfaatannya menjadi pupuk organik, lindi difermentasikan menggunakan bakteri penambat $\mathrm{N}$, yaitu Azospirillum. Tujuan penelitian ini adalah untuk mengetahui pengaruh pengenceran lindi dengan konsentrasi bakteri starter terhadap laju pertumbuhan tanaman pangan yang baik. Variabel yang digunakan adalah pengenceran lindi dan konsentrasi penambahan bakteri starter. Pengenceran yang digunakan yaitu 50x, 75x, 100x, dengan volume sampel sebanyak $10 \mathrm{ml}$. penelitian ini dilakukan dalam skala laboratorium dengan tanaman uji berupa Sorghum bicolor dan Zea mays. Proses fermentasi pada masing-masing reaktor uji dilakukan selama 14 hari. Analisis dilakukan pada jumlah koloni bakteri, $\mathrm{BOD}_{5}$, COD, amonium, nitrat, serta parameter fisik berupa pH dan suhu. Hasil dari penelitian berupa besarnya pertambahan batang dan daun tanaman uji. Pertambahan tinggi batang tanaman yang terbaik adalah penambahan dari pupuk D1 untuk tanaman Sorghum bicolor dan D2 untuk tanaman Zea mays. Kedua pupuk tersebut memberikan pengaruh yang signifikan terhadap pertumbuhan tanaman uji.
\end{abstract}

Kata Kunci-bakteri, lindi, pupuk, Sorghum bicolor, Zea mays

\section{PENDAHULUAN}

$\mathrm{P}$ ERTAMBAHAN jumlah penduduk yang diikuti dengan bertambahnya volume, jenis serta karakteristik sampah telah menjadi sebuah permasalahan. Sehingga perlu dilakukan pengelolaan yang baik. Ada beberapa pengelolaan sampah yang dapat dilakukan. Diantaranya adalah pengurangan dan penanganan sampah. Salah satu sarana penanganan sampah adalah Stasiun Peralihan Antara (SPA). Salah satu SPA yang terdapat di Surabaya dan aktif hingga saat ini adalah SPA Rangkah. Pada SPA Rangkah terdapat unit pereduksi volume. Unit ini berupa alat pemadat yang dapat mereduksi volume sekaligus mengurangi kadar air di dalam sampah. Dalam ketentuan Kementerian Pekerjaan Umum, pada pengoperasian SPA disyaratkan minimal menyediakan bak penampung lindi. Bak ini berfungsi untuk menampung kadar air dari sampah yang telah melalui proses pemadatan.

Lindi berbentuk cairan dan dapat mengandung bibit penyakit. Lindi merupakan air yang terbentuk dalam timbunan sampah yang melarutkan banyak senyawa [1]. Sehingga memiliki kandungan pencemar khususnya zat organik yang sangat tinggi. Oleh sebab itu, lindi berpotensi menimbulkan pencemaran, baik pencemaran air tanah maupun air permukaan. Disamping memiliki dampak negatif berupa adanya pencemaran, lindi juga memiliki dampak positif. Lindi memiliki unsur-unsur yang dibutuhkan oleh tanaman. Unsur tersebut antara lain, organik Nitrogen (10-600 mg/L), Amonium Nitrogen (10$800 \mathrm{mg} / \mathrm{L})$, Nitrat (5-40 mg/L), Fosfor Total (1-70 mg/L), Total besi (50-600 mg/L) [2]. Sehingga, air lindi memiliki potensi untuk dimanfaatkan sebagai pupuk organik. Pada penelitian ini dilakukan pemanfaatan lindi yang dihasilkan oleh sampah-sampah di SPA Rangkah. Lindi dimanfaatkan dengan cara fermentasi. Fermentasi dilakukan dengan penambahan bakteri penambat N. Penambahan bakteri starter penambat $\mathrm{N}$ ditujukan untuk menyediakan unsur $\mathrm{N}$ yang cukup bagi tanaman uji. Hasil dari fermentasi tersebut kemudian dimanfaatkan sebagai pupuk organik untuk tanaman pangan, yaitu sorgum (Sorghum bicolor) dan jagung (Zea mays).

Azospirillum yang merupakan bakteri penambat $\mathrm{N}$ mampu menambat nitrogen $\left(\mathrm{N}_{2}\right)$ 40-80\% dari total nitrogen [3]. Bakteri ini mampu menambat nitrogen bebas lebih baik daripada bakteri tanah penambat nitrogen lainnya [4]. Penggunaan bakteri penambat N (Azospirillum) ditujukan untuk membantu pertumbuhan vegetatif tanaman uji, terutama pada pertumbuhan batang tanaman serta pertumbuhan daun.

Berdasarkan latar belakang di atas, maka teknik pemanfaatan lindi dilakukan dengan fermentasi lindi menggunakan bakteri Azospirillum. Pada penelitian ini juga terdapat variasi penambahan bakteri Azospirillum pada lindi yang telah diencerkan. Hal tersebut dilakukan untuk mengetahui konsentrasi yang paling baik dalam pembentukan pupuk organik cair. Hasil dari proses fermentasi yang berupa pupuk organik, diberikan ke tanaman uji dengan pengukuran tinggi batang dan jumlah daun tanaman pangan yang diuji.

\section{METODE PENELITIAN}

Pada penelitian ini reaktor yang digunakan berupa botol kaca berukuran 1 liter. Sebanyak $10 \mathrm{~mL}$ lindi dimasukkan ke dalam reaktor uji kemudian diencerkan dengan variasi 50, 75, dan 100. Setelah pengenceran pada lindi, kemudian juga dimasukkan bakteri starter dengan variasi 0,5 gram dan 2 gram untuk bakteri starter yang berbentuk serbuk, serta 5 $\mathrm{mL}$ dan $10 \mathrm{~mL}$ untuk bakteri starter yang berbentuk cair. Terdapat 2 macam perlakuan pada penelitian ini, yaitu kontrol dan reaktor uji. Kontrol merupakan reaktor dengan perlakuan variasi pengenceran tanpa penambahan bakteri starter. Sedangkan reaktor uji lain menggunakan variasi pengenceran lindi sekaligus penambahan bakteri penambat N (Azospirillum). 
Proses fermentasi pada penelitian ini dilakukan selama 14 hari. Pada awal penelitian, sebelum proses fermentasi, dilakukan uji parameter $\mathrm{BOD}_{5}$, $\mathrm{COD}$, amonium, dan nitrat. Sedangkan selama penelitian berlangsung, dilakukan perhitungan pada jumlah koloni bakteri pada hari ke-7 dan ke-14 proses fermentasi. Analisis jumlah koloni bakteri dilakukan dengan metode TPC (Total Plate Count). Adapun analisis lain yang dilakukan setelah proses fermentasi berlangsung adalah analisi pada nilai amonium, nitrat, $\mathrm{BOD}_{5}$, dan COD hasil fermentasi.

Pupuk yang telah terbentuk dari proses fermentasi diberikan ke tanaman uji berupa tanaman sorgum (Sorghum bicolor) dan jagung (Zea mays). Kemudian dilakukan pengamatan tiap 3 hari sekali pada tinggi batang dan jumlah daun tanaman uji. Setelah itu, dilakukan uji statistik untuk mengetahui signifikansi terhadap pertumbuhan tanaman.

\section{HASIL DAN PEMBAHASAN}

Selama 14 hari proses fermentasi dilakukan perhitungan jumlah koloni bakteri. Sedangkan parameter yang berupa parameter fisika dan kimiawi di uji pada awal dan akhir proses fermentasi. Pupuk yang telah mengalami prosesfermentasi kemudian diberikan ke tanaman uji dan dilakukan pengamatan tiap 3 hari sekali pada tinggi dan daun tanaman uji.

\section{A. Jumlah Koloni Bakteri}

Pengamatan jumlah koloni bakteri dilakukan untuk mengetahui jumlah bakteri yang hidup selama proses fermentasi berlangsung. Perhitungan jumlah koloni bakteri dilakukan menggunakan metode TPC (Total Plate Count). Pengamatan jumlah koloni bakteri dilakukan pada hari ke-7, dan ke-14. Adapun hasil perhitungan jumlah koloni bakteri selama proses fermentasi dapat dilihat pada Gambar 1 dan Gambar 2.

Berdasarkan Gambar 1 dan Gambar 2 dapat diketahui bahwa rata-rata bakteri pada reaktor uji mengalami penurunan dari hari ke-7 hingga hari ke-14 (akhir fermentasi), kecuali pada reaktor uji B1 yang mengalami kenaikan jumlah koloni bakteri. Reaktor B1 merupakan reaktor yang mendapat perlakuan penambahan bakteri sebanyak 1 gram dan pengenceran lindi sebanyak 50 kali. Hal ini disebabkan oleh fase pertumbuhan bakteri yang mulai menurun akibat berkurangnya nutrisi yang tersedia pada reaktor uji. Selama proses fermentasi hingga hari ke-7, jumlah koloni terbesar ada pada reaktor dengan penambahan biaoktivator serbuk 1 gram dengan pengenceran 100 kali (Reaktor B3). Perlakuan pengenceran dan penambahan bioaktivator yang dilakukan berpengaruh pada jumlah koloni bakteri yang ada pada reaktor uji. Selain itu, jumlah koloni bakteri juga dipengaruhi oleh adanya bakteri bakteri pada sampel air lindi. Dari keenam reaktor uji yang ditambahkan bioaktivator serbuk, bakteri masih dapat hidup dan berkembang biak hingga hari ke-14 proses fermentasi.

Sedangkan pada reaktor dengan penambahan bioaktivator cair (Gambar 2), dapat diketahui bahwa hampir semua reaktor uji mengalami penurunan jumlah koloni bakteri kecuali pada reaktor uji D1 dan D2. Reaktor D1 adalah reaktor uji yang mendapatkan perlakuan penambahan bioaktivator cair $10 \mathrm{~mL}$ dengan pengenceran lindi sebesar 50 kali. Sedangkan reaktor D2 adalah reaktor yang mendapat perlakuan penambahan bioaktivator cair $10 \mathrm{~mL}$ dengan pengenceran lindi sebesar 75 kali. Fluktuasi jumlah koloni bakteri tersebut dipengaruhi oleh beberapa faktor antara lain nutrisi makanan, suhu, dan derajat kemasaman (pH).

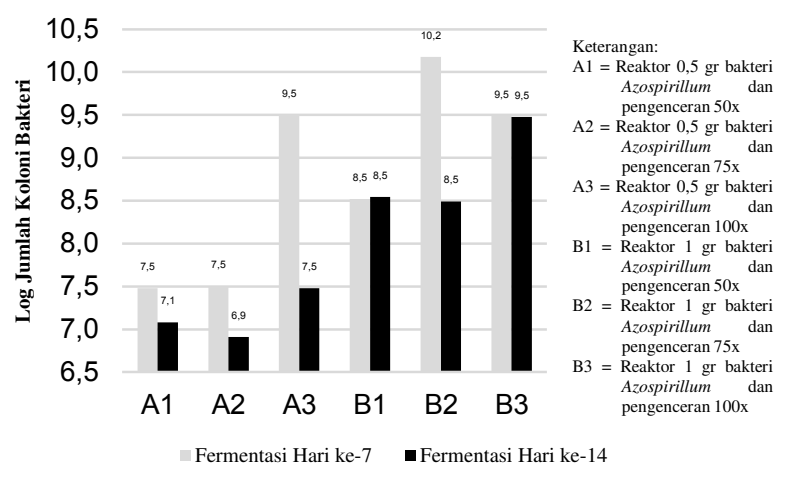

Gambar 1. Jumlah Koloni Bakteri Pada Reaktor Uji Dengan Penambahan Bioaktivator Serbuk
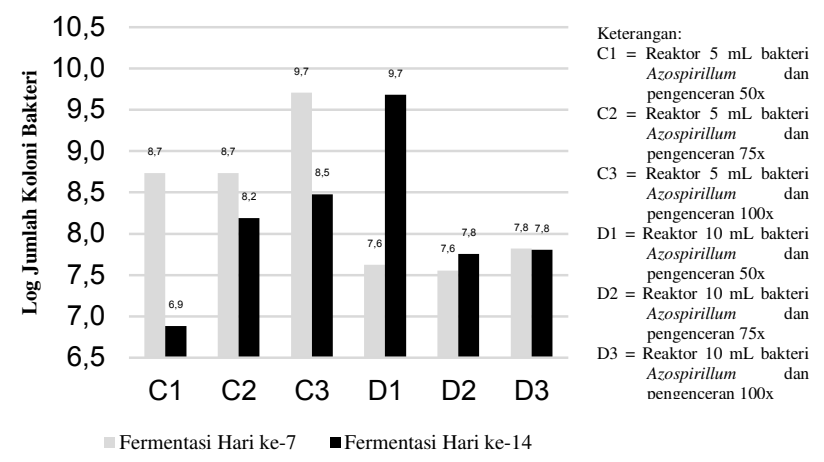

Gambar 2. Jumlah Koloni Bakteri Pada Reaktor Uji Dengan Penambahan Bioaktivator Cair

Mikroorganisme dalam reaktor uji memanfaatkan bahan organik dalam lindi untuk berkembang biak. Hal ini sesuai dengan rujukan [5], yang menyatakan bahwa pemanfaatan bahan organik dalam limbah cair mengakibatkan jumlah mikroorganisme di dalamnya juga mengalami fluktuasi. Sedangkan menurut rujukan [6], Azospirillum termasuk bakteri yang tumbuh lambat. Sehingga pada pengamatan dan perhitungan jumlah koloni bakteri yang dilakukan oleh peneliti, hasilnya tidak terlalu besar.

Perhitungan jumlah koloni bakteri juga dilakukan pada reaktor uji kontrol di akhir proses fermentasi. Hasil perhitungan jumlah koloni bakteri dapat dilihat pada Gambar 3.

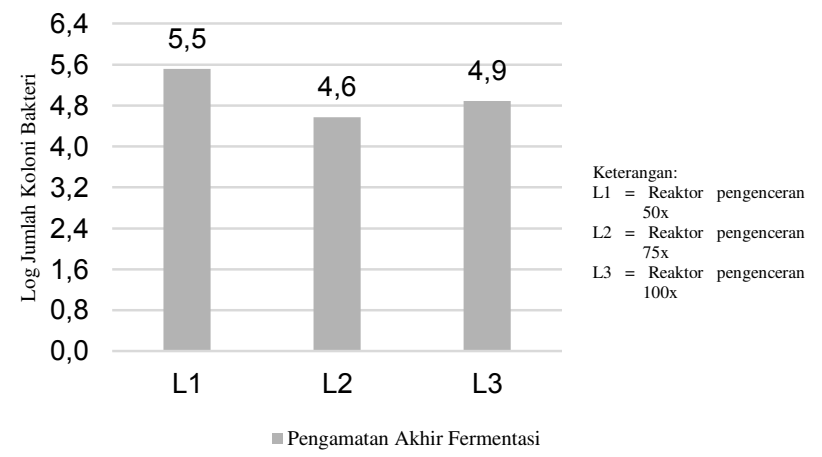

Gambar 3. Jumlah Koloni Bakteri Pada Reaktor Kontrol

Dari Gambar 3, dapat diketahui bahwa jumlah bakteri yang teramati pada penelitian masih sedikit jika dibandingkan dengan reaktor uji lain. Hal ini menandakan 
bahwa pada lindi tidak mengandung terlalu banyak bakteri. Pada reaktor kontrol tidak dilakukan penambahan bakteri penambat N (Azospirillum). Sehingga jumlah koloni bakteri yang teramati pada uji koloni bakteri tidak terlalu banyak.

\section{B. Parameter Fisika}

Parameter fisika merupakan parameter fisik yang diukur pada reaktor uji yang meliputi nilai $\mathrm{pH}$ dan suhu. Parameter ini diukur pada akhir proses fermentasi sebelum pupuk diberikan ke tanaman uji. Parameter $\mathrm{pH}$ pada reaktor uji diukur pada akhir proses fermentasi (hari ke-14). Hasil pengukuran $\mathrm{pH}$ pada reaktor uji dapat dilihat pada Gambar 4.

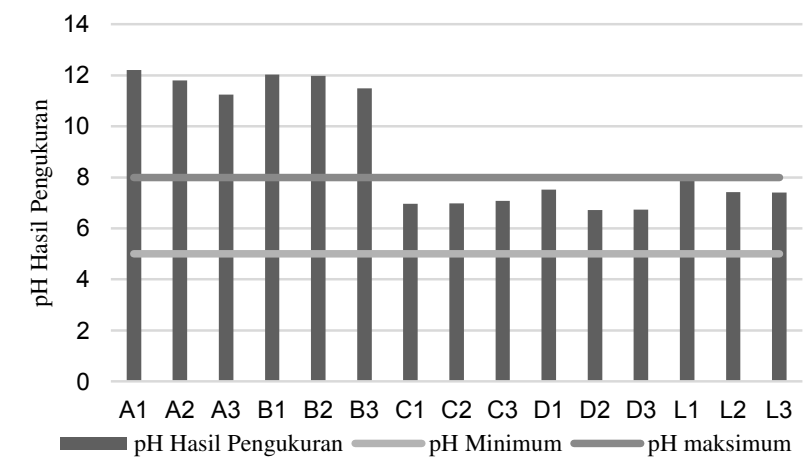

Gambar 4. pH Hasil Pengukuran

Berdasarkan Gambar 4, dapat diketahui bahwa reaktor uji dengan penambahan bioaktivator cair dan reaktor kontrol sudah memenuhi persyaratan minimal $\mathrm{pH}$ pupuk yang disyaratkan oleh Menteri Pertanian, yaitu peraturan Nomor 70/Permentan/SR.140/10/2011 dengan nilai pH yang disyaratkan adalah 5 hingga 8 . Sedangkan pada reaktor uji dengan penambahan bioaktivator serbuk belum memenuhi nilai $\mathrm{pH}$ yang disyaratkan. Sebelum pupuk cair yang berasal dari reaktor uji dengan perlakuan penambahan bioaktivator serbuk diberikan ke tanaman uji, dilakukan proses pengenceran terlebih dahulu. Hal ini ditujukan untuk menurunkan nilai $\mathrm{pH}$ pupuk. Hasil pengukuran $\mathrm{pH}$ pada reaktor uji dengan penambahan bioaktivator serbuk dapat dilihat pada Gambar 5.

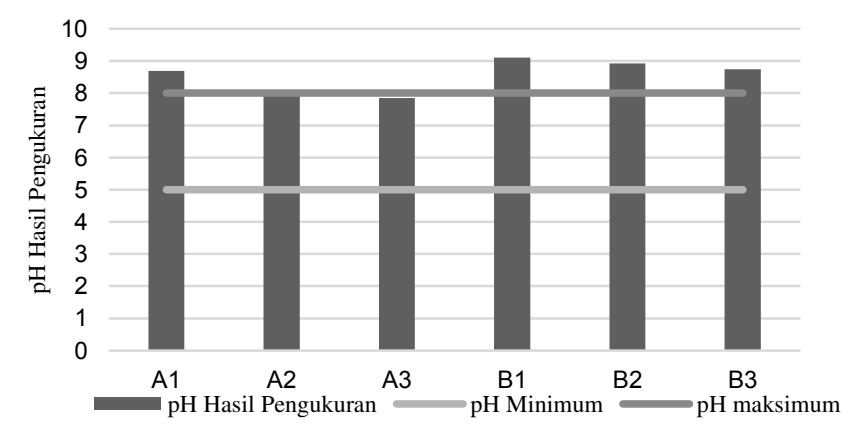

Gambar 5. pH Hasil Pengukuran Setelah Pengenceran

Berdasarkan Gambar 5, dapat diketahui bahwa pH beberapa pupuk belum sesuai dengan peraturan yang berlaku. Pada akhir fermentasi, $\mathrm{pH}$ pada raktor uji masih dianggap baik dan dalam ambang batas normal, karena tidak mempengaruhi aktivitas bakteri Azospirillum dan bakteri Azospirillum dapat bertahan hidup dan berkembang biak pada kondisi $\mathrm{pH}$ basa.
Suhu diukur pada akhir proses fermentasi menggunakan terrmometer. Hasil pengukuran suhu pada reaktor fermentasi dapat dilihat pada Gambar 6. Suhu pada reaktor uji adalah antara $31^{\circ} \mathrm{C}-32^{\circ} \mathrm{C}$. Sehingga pada akhir fermentasi, suhu pada reaktor uji masih dianggap baik dan tidak mempengaruhi aktivitas bakteri dalam reaktor uji.

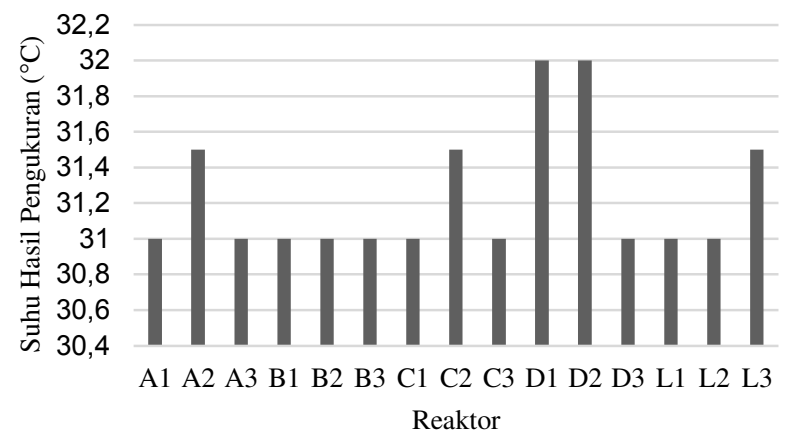

Gambar 6. Suhu Hasil Pengukuran

\section{Parameter Kimiawi}

Parameter kimiawi meliputi uji amonium, nitrat, $\mathrm{BOD}_{5}$ dan COD pada reaktor uji dilakukan di awal dan akhir proses fermentasi. Tanaman pada umumnya menyerap nitrogen dalam bentuk $\mathrm{NH}_{4}^{+}$atau $\mathrm{NO}_{3}^{-}$. Oleh kareana itu perlu dilakukan uji amonium dan nitrat pada reaktor uji. Uji amonium yang dilakukan di awal proses fermentasi menunjukkan hasil 60,2 $\mathrm{mg} / \mathrm{L}$. Sedangkan hasil perubahan amonium pada akhir proses fermentasi dapat dilihat pada Gambar 7.

Dari Gambar 7 dapat diketahui bahwa amonium mengalami kenaikan dari nilai amonium awal pengukuran (sebelum fermentasi). Hal ini sejalan dengan tujuan dari proses fermentasi. Yaitu menaikkan nilai nitrogen yang diserap tanaman. Amonium dapat terbentuk melalui peristiwa penguraian organisme yang sudah mati baik tumbuhan ataupun hewan oleh mikroorganisme [7]. Selain itu, lindi mengandung sisa-sisa organik dari sampah organik di SPA Rangkah, sehingga terbentuk amonium yang tinggi pada reaktor uji.

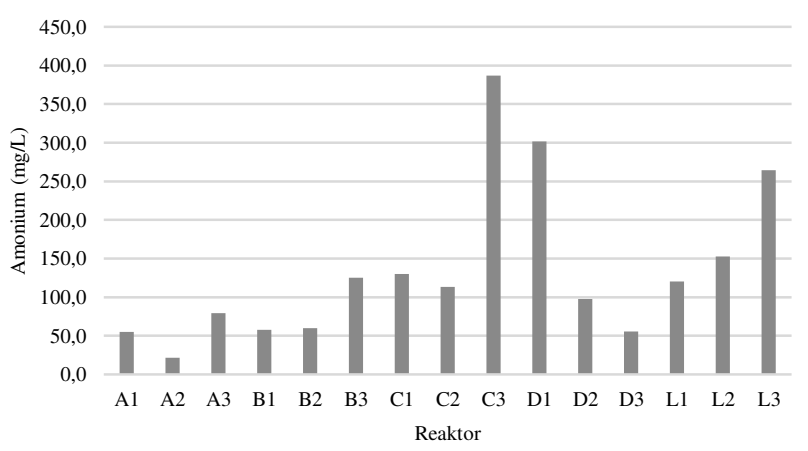

Gambar 7. Perubahan Nilai Amonium

Uji nitrat yang dilakukan pada awal proses fermentasi terukur sebanyak 5,028 mg/L. Sedangkan pada akhir proses fermentasi, perubahan nitrat dapat dilihat pada Gambar 8 . 


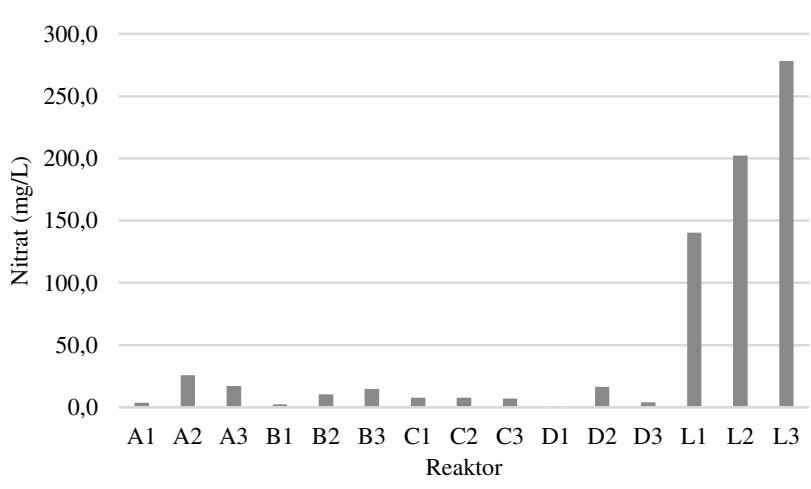

Gambar 8. Perubahan Nilai Nitrat

Dari Gambar 8, dapat diketahui bahwa nitrat mengalami kenaikan dari nilai awal pengukuran (sebelum fermentasi). Amonium akan membentuk reaksi keseimbangan dengan amonia [8]. Sehingga sebagian amonia dioksidasi oleh bakteri pada keadaan anaerobik dan berlangsung proses nitrifikasi menghasilkan nitrat. Sehingga pada proses fermentasi ini, amonium akan mengalami proses nitrifikasi dan membentuk nitrit dan nitrat. Pada proses anaerobik, akan terjadi penurunan kandungan amonium ditandai dengan adanya oksidasi amonium oleh nitrit [9]. Amonium ini yang kemudian mengalami proses nitrifikasi membentuk nitrit dan nitrat [10]. Terdapat 2 proses dekomposisi bahan organik yaitu tahap pertama berupa degradasi bahan organik menjadi bahan anorganik, kemudian tahap kedua yaitu perubahan bahan anorganik tidak stabil menjadi bentuk yang lebih stabil seperti amonia menjadi nitrit dan nitrat [11]. Sehingga, nitrat akan mengalami kenaikan pada prosesnya [12]. Hal ini disebabkan terjadinya proses nitrifikasi yang membentuk nitrat.

$\mathrm{Uji}^{\mathrm{BOD}_{5}}$ dan COD juga dilakukan pada awal dan akhir proses fermentasi. hasil uji $\mathrm{BOD}_{5}$ dan $\mathrm{COD}$ dapat dilihat pada Gambar 9 dan Gambar 10.

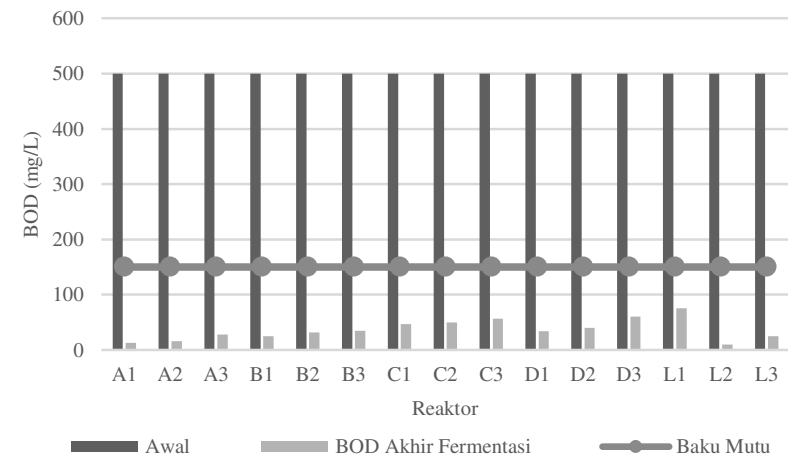

Gambar 9. Penurunan Nilai BOD 5

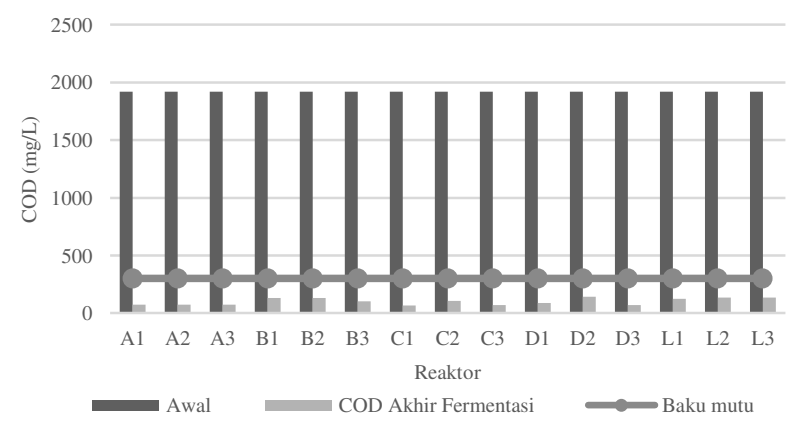

Gambar 10. Penurunan Nilai COD
Dari Gambar 9 dan Gambar 10 dapat diketahui bahwa nilai $\mathrm{BOD}_{5}$ dan $\mathrm{COD}$ hasil pengukuran mengalami penurunan jika dibandingkan dengan sebelum dilakukan proses fermentasi. Proses penurunan $\mathrm{BOD}_{5}$ dan $\mathrm{COD}$ terjadi pada semua reaktor uji. Penurunan kandungan senyawa organik dapat menurunkan nilai $\mathrm{BOD}_{5}$ [13]. Penurunan kandungan senyawa organik tersebut, disebabkan oleh aktivitas mikroorganisme di dalam reaktor. Selain itu, penurunan nilai $\mathrm{BOD}_{5}$ terjadi karena menurunya jumlah bahan organik dan jumlah bakteri yang menguraikan bahan organik dalam lindi [14]. Sedangkan pada COD, proses pemecahan atau degradasi senyawa organik yang terjadi pada reaktor uji menjadi senyawa yang lebih sederhana akan menurunkan nilai COD [13].

Nilai $\mathrm{BOD}_{5}$ pada akhir proses fermentasi telah memenuhi baku mutu yang disyaratkan oleh Peraturan Menteri Lingkungan Hidup dan Kehutanan Nomor P.59/Menlhk/ Setjen/Kum.1/7/2016, yaitu sebesar 150 mg/L. Begitu juga dengan COD yang telah memenuhi baku mutu, yaitu sebesar $300 \mathrm{mg} / \mathrm{L} \mathrm{O}_{2}$. Nilai $\mathrm{BOD}_{5}$ dan $\mathrm{COD}$ hasil pengukuran menunjukkan bahwa air lindi pada semua reaktor uji dapat dikembalikan ke lingkungan.

\section{Pengamatan Tanaman Uji}

Pemberian pupuk ke tanaman uji dilakukan seminggu sekali dengan pengamatan 3 hari sekali. Pengamatan yang dilakukan adalah pengukuran terhadap tinggi batang dan jumlah daun tanaman uji. Pengamatan terhadap perubahan tinggi batang tanaman sorgum dapat dilihat pada Gambar 11 .

Pada Gambar 11, dapat diketahui bahwa tinggi batang tanaman sorgum terbesar yaitu pada tanaman yang diberi pupuk kimia. Sedangkan pada tanaman yang diberi pupuk lindi, pertumbuhan tanaman tertinggi pada tanaman yang diberi pupuk D1 (penambahan bakteri starter cair). Hal ini sesuai dengan rata-rata nilai amonium, nitrat, dan jumlah koloni bakteri terbesar adalah pada reaktor D1. Berdasarkan uji ANOVA untuk mengetahui signifikansi pupuk terhadap tanaman, dapat diketahui bahwa pupuk yang memberikan pengaruh yang signifikan terhadap petumbuhan tinggi batang tanaman sorgum adalah pupuk D1 dan D2.

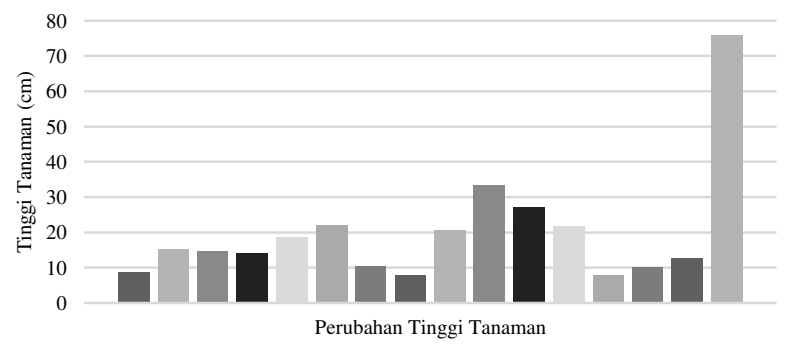

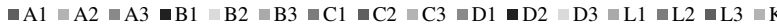

Gambar 11. Perubahan Tinggi Batang Tanaman Sorgum

Respon yang baik dari tanaman sorgum menunjukkan bahwa kebutuhan $\mathrm{N}$ tanaman tersebut mampu dipenuhi oleh pupuk organik. Lindi yang mengandung bahan-bahan organik serta penambahan bakteri starter penambat $\mathrm{N}$, mampu menyediakan unsur hara yang cukup untuk pertumbuhan batang tanaman sorgum pada reaktor D1 dan D2. Hal ini menunjukkan bahwa tanaman sorgum memberikan respon yang baik pada pengenceran dibawah 100 kali dengan konsentrasi bakteri Azospirillum yang 
cukup untuk menunjang penambatan $\mathrm{N}$ bagi tanaman sorgum. Pupuk organik yang diberikan ke tanaman uji memiliki fungsi kimia yang penting seperti penyediaan hara makro (N, P, K, Ca, Mg, dan S) dan mikro (Zn, Cu, Mo, Co, $\mathrm{B}, \mathrm{Mn}$, dan $\mathrm{Fe}$ ) [15].

Sedangkan untuk pengamatan terhadap jumlah daun sorgum dapat dilihat pada Gambar 12.

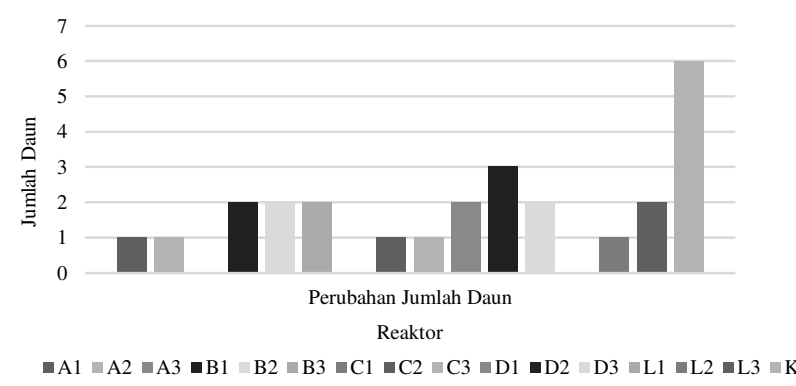

Gambar 12. Perubahan Jumlah Daun Tanaman Sorgum

Pada Gambar 12, dapat diketahui bahwa jumlah daun tanaman sorgum terbesar yaitu pada tanaman yang diberi pupuk kimia. Sedangkan pada tanaman yang diberi pupuk lindi, pertambahan jumlah daun tertinggi pada tanaman yang diberi pupuk D1 (penambahan bakteri starter cair). Hal ini sesuai dengan rata-rata nilai amonium, nitrat, dan jumlah koloni bakteri terbesar adalah pada reaktor D1. Untuk mengetahui signifikansi pupuk terhadap tanaman, maka dilakukan uji ANOVA dengan $\mathrm{P}<0,05$. Hasil menunjukkan bahwa semua jenis pupuk memberikan pengaruh yang tidak signifikan terhadap pertambahan daun tanaman sorgum. Hara $\mathrm{N}$ terlibat langsung dalam pembentukan asam amino, protein, asam nukleat, enzim, nucleoprotein, dan alkaloid, yang sangat dibutuhkan untuk proses pertumbuhan tanaman, terutama perkembangan daun, meningkatkan warna hijau daun, serta pembentukan cabang atau anakan [16]. Namun pada perkembangan daun sorgum, hara $\mathrm{N}$ yang tersedia belum mampu memenuhi kebutuhan hara $\mathrm{N}$ tanaman uji untuk daun.

Pengamatan terhadap tinggi tanaman jagung dapat dilihat pada Gambar 13.

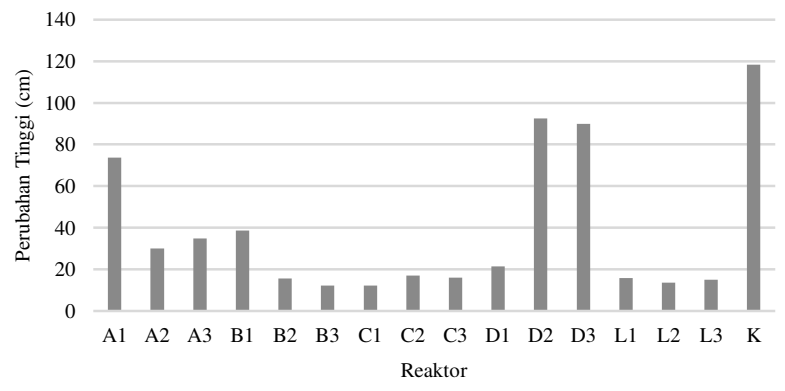

Gambar 13. Perubahan Tinggi Batang Tanaman Jagung

Pada Gambar 13, dapat diketahui bahwa tinggi batang tanaman jagung terbesar yaitu pada tanaman yang diberi pupuk kimia. Sedangkan untuk tanaman yang diberi pupuk dari lindi adalah dengan penambahan pupuk D2. Kemudian dilakukan uji ANOVA untuk mengetahui signifikansi jenis pupuk terhadap pertumbuhan tanaman. Hasil signifikansi menunjukkan bahwa beberapa pupuk yang memberikan pengaruh signifikan yaitu pada pupuk jenis A1, B1, D2, dan D3.
Suatu tanaman akan tumbuh dengan subur apabila unsur yang dibutuhkan tersedia cukup [17]. Jenis pupuk A1, B1, D2, dan D3 menyediakan unsur hara yang cukup untuk tanaman jagung sehingga batang tanaman jagung tumbuh lebih tinggi. Interaksi antara Azospirillum serta unsur hara yang tersedia pada lindi di pupuk organik baik dari bakteri starter serbuk maupun cair menyebabkan tersedianya hara, khususnya $\mathrm{N}$ untuk tanaman. Adanya aktivitas bakteri starter dalam tanah menyebabkan terjadinya mobilisasi hara dalam tanah sehingga tersedia bagi tanaman [18]. Selain itu, bakteri starter di tanah juga menghasilkan hormon tumbuh yang sangat mempengaruhi interaksi dengan tanaman. Keempat jenis pupuk yang signifikan tersebut mampu memberikan hara yang cukup untuk pertumbuhan tanaman jagung. Hal ini dimungkinkan karena adanya bakteri tanah atau mikroba tanah pada jagung ditambah dengan pupuk organik dari reaktor uji yang memiliki bakteri starter penambat N. Pemberian pupuk dengan dosis yang tepat akan berperan dalam meningkatkan ketersediaan unsur hara di dalam tanah, sehingga akan mempengaruhi tingkat pertumbuhan dan produksi tanaman [19].

Pengamatan terhadap jumlah daun tanaman jagung dilakukan dapat dilihat pada Gambar 14.Pada Gambar 14, dapat diketahui bahwa jumlah daun tanaman jagung terbesar yaitu pada tanaman yang diberi pupuk D2. Adapun untuk mengetahui tingkat signifikansi jenis pupuk terhadap jumlah daun tanaman jagung, maka dilakukan uji signifikansi. Berdasarkan uji ANOVA yang telah dilakukan dapat diketahui bahwa semua pupuk memberikan pengaruh yang sama terhadap pertumbuhan daun tanaman sorgum. Sehingga semua jenis pupuk memberikan pengaruh yang tidak signifikan terhadap pertumbuhan daun tanaman uji.

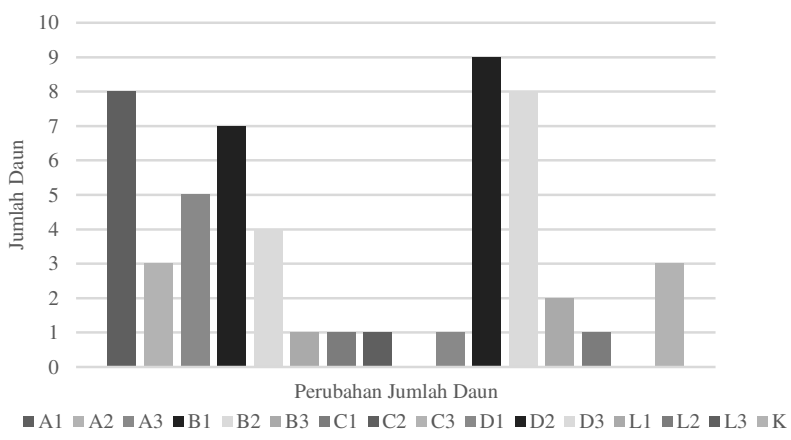

Gambar 14. Perubahan Jumlah Daun Tanaman Jagung

Pengaruh yang lambat dan tidak signifikan tersebut, mungkin disebabkan karena kemampuan akar tanaman untuk menyerap pupuk belum berfungsi sempurna akibatnya pupuk tidak terserap maksimal. Penyebab lain adalah sifat dari pupuk organik hayati yang "slow release" sehingga membutuhkan waktu yang agak lama untuk melihat pengaruh dari pupuk organik [20]. Selain pengaruh penambahan pupuk, pertumbuhan tanaman dipengaruhi oleh adanya cahaya matahari yang membantu proses fotosintesis, sera pengaruh penyiraman. Selain itu, pertumbuhan tanaman uji juga dipengaruhi oleh tersedianya unsur hara, terutama nilai $\mathrm{N}$ pada tanah dan selama pemberian pupuk.

\section{KESIMPULAN}

Berdasarkan penelitian yang telah dilakukan, maka dapat diambil kesimpulan sebagai berikut:

1. Konsentrasi penambahan bakteri starter serta pengenceran lindi dalam menghasilkan pupuk yang 
baik yaitu D1 (reaktor dengan penambahan bakteri starter cair sebanyak $10 \mathrm{~mL}$ dan pengenceran sebesar 50 kali) dan B3 (reaktor dengan penambahan bakteri starter serbuk sebanyak 1 gram dan pengenceran sebesar 100 kali).

2. Pertumbuhan tinggi batang tanaman sorgum paling cepat terjadi pada pemberian pupuk cair D1. Sedangkan pada tanaman jagung pada pemberian pupuk cair D2. Kedua pupuk tersebut berpengaruh signifikan pada tanaman sorgum dan jagung menurut hasil ANOVA. Sedangkan pada jumlah daun, semua jenis pupuk memberikan pengaruh yang tidak signifikan menurut hasil ANOVA.

\section{UCAPAN TERIMA KASIH}

Penulis mengucapkan terimakasih kepada Stasiun Peralihan Antara Rangkah, Laboratorium Teknologi Pengolahan Air, Laboratorium Limbah Padat dan B3, dan semua pihak, atas bantuan dan arahan yang telah diberikan kepada penulis selama penelitian berlangsung.

\section{DAFTAR PUSTAKA}

[1] Darmasetiawan, Martin. 2004. Perencanaan Tempat Pembuangan Akhir (TPA). Jakarta: Ekamitra Engineering

[2] Tchobanoglous, G., Vigil, S. 1993. Integrated Solid Wastes Management Issues. New York: International Edition Mc Grow Hill

[3] Samekto, R. 2008. Bioteknologi dan Keharaan Tanaman (Mikroorganisme, Nitrogen, dan Fosfor). J. Inov. Pertan. 7:66-85

[4] Traversi D, Romanazzi V, Degan R, Lorenzi E,Carraro E, Gilli G. 2015. Microbialchemical indicator for anaerobic digester performance assessment in full-Scale waste water treatment plants for biogas production. J Biores Technol. 186: 179 - 191.

[5] Widawati., Muharram. 2012. Uji Laboratorium Azospirillum sp yang Diisolasi dari Beberapa Ekosistem. J. Hort. 22(3):258-267, 2012

[6] Pandey, S. N., Sinha B. K. 1990. Plant Physiologi 2nd Revised Edition. Kanpur: Vikas Publishing House

[7] Li H, Zhou S, Mae W, Huang P, Huang G, Qin Y, Xu B, Ouyang H. 2014. Long-term performance and microbial ecology of a two-stage PN-ANAMMOX process treating mature landfill leachate. J Biores Technol. 159: 404-411.

[8] Nindrasari GV, Meitiniarti I, Jubhar C, Mangimbulude. 2010. Pengurangan ammonium dengan metode nitrifikasi dan anammox pada air lindi dari tempat pembuangan sampah Jati Barang Semarang. Seminar Nasional VIII Pendidikan Biologi. Biologi, Sains, Lingkungan dan Pembelajarannya Menuju Pembangunan Karakter. Semarang: 21-23 September 2010.

[9] Damsir, Suprihatin, M Romli, M Yani, Arie H. 2016. Karakteristik Lindi Hasil Fermentasi Anaerobik Sampah Kota dalam Lisimeter dan Potensi Pemanfaatannya Menjadi Pupuk Cair. Jurnal Teknologi Pertanian 26 (2):125-133 (2016)

[10] Chen ,Y., Cheng, J.J., Creamer, K.S. 2008. Inhibition of anaerobic digestion process: A review. J Biores Technol. 99(10): 4044- 4060

[11] Iswanto, B., Widyo Astono, Sunaryati.2007. Pengaruh Penguraian Sampah Terhadap Kualitas Air Ditinjau Dari Perubahan Senyawa Organik dan Nitrogen dalam Reaktor Kontinyu Skala Laboratorium. Jakarta: Universitas Trisakti

[12] Avlenda, E. 2009. Penggunaan tanaman kangkung (Ipomoea aquatica) Forsk.) dan genjer (Limnocharis Flava (L.) Buch.) dalam pengolahan limbah cair pabrik kelapa sawit. [Tesis]. Bandung. Institut Teknologi Bandung

[13] Eko, M., Wiryanto, Sajidan. 2006. Pengolahan Limbah Domestik dengan Aerasi dan Penambahan Bakteri Pseudomonas putida. Jurnal Bioteknologi 3 (2): 42-49, Nopember 2006

[14] Simanungkalit, R.D.M. 2006. Pupuk Organik dan Pupuk Hayati. Bogor: Balai Besar Penelitian dan Pengembangan Sumberdaya Lahan Pertanian

[15] Nasreen, S, Haque, MM, Hosain, MA \& Farid, ATM .2007. Nutrient uptake and yield of onion as influenced by nitrogen and sulphur fertilization, Bangladesh. J. Agril. Res., vol. 32, no. 3, pp. 413-20.

[16] Abdissa, Y, Tekallign, T \& Pant, LM. 2011. Growth, bulb yield, and quality of onion (Allium cepa L.) as influenced by nitrogen and phosphorus fertilization on vertisol. I. growth attributes, biomass production and bulb yield. Afr. J. Agric. Res., vol. 6, no. 14, pp. 3252-8
[17] Dwidjoseputro. 1990. Pengantar FIsiologi Tumbuhan. Jakarta: PT. Gramedia Pustaka Utama

[18] Rao, N.M.S. 1982. Biofertilizers in Agriculture. New Delhi:Oxford and BH Publishing Co

[19] Marsono dan P. Sigit. 2000. Pupuk AkarJenis dan Aplikasinya. Jakarta: Penebar Swadaya.

[20] Gubali, H., M. I. Bahua, N. Musa. 2013. Uji Efektivitas Pupuk Organik Hayati untuk Meningkatkan Pertumbuhan dan Hasil Tanaman Kangkung Darat. Gorontalo:Universitas Negeri Gorontalo 